\title{
Result of Marianum Antigen in the Treatment of Leprosy
}

\author{
ARTEMIO BAGALAWIS, M.D., ELIZABETH OH, м.D. \\ (the late) MARGARET WHANG, M.D. \\ Catholic Leprosy Service, Seoul, Korea
}

\section{N T R O DUCT I ON}

We present a report on patients who were treated principally with Marianum Antigen at eight small leprosaria and 70 treatment stations in six provinces of Korea at least once a month by stationary and mobile clinics.

The total number of patients was over i i, ooo listed by seven doctors, among whom 6,605 were registered by Drs Bagalawis, Oh and Whang, who worked a much longer term than our other doctors, but for this paper only 2,869 were selected who came regularly for treatment and observation up to $7 \frac{1}{2}$ years. Of the 2,869 treated, 2,502 had M.A. therapy and the other 367 cases were divided into two therapy groups for comparison. The great majority omitted from this report were inmates of leprosaria given over to other control, or wandering patients, forced from place to place by the public or the police, of whom track was lost. Many expecting too rapid a cure came and went then disappeared; and some died.

Except 687 living in leprosaria nearly all of the 2,869 were home patients. They were treated at 70 stations; many of them had no shelter except bridges and crematoria, so that often the patients were exposed to bad weather and to the curiosity of passers-by. Advanced patients usually could not use public transport some having to walk up to Io miles. But all cited here were faithful in meeting our clinics at fixed places, days and hours.

The majority had no previous care from any doctor and had only self-treatment, if any. Few have means to support themselves. Some work hard as day-labourers, some have to beg for their living. Without the monthly food supply, which we try to distribute, about 20 lbs of grain, many would verge on starvation.
Most of the wandering patients had been in leprosaria under sulphone therapy. Some were discharged as negative patients and nearly all were stationery patients but of ten needing care for concurrent diseases. Some had narcotic or alcoholic habits and had gone off as wandering beggars. Home patients in fear of segregation shun government officials.

Mobile clinics seem to be the best means of taking care of these patients, to examine their contacts in view of early treatment, to follow up suspicious cases and to prevent the spread of the disease.

\section{METHOD EMPLOYED}

$$
\begin{array}{lll}
\text { Group } A & \ldots & \text { M.A. - Marianum Antigen } \\
\text { Group B } & \ldots & \text { DDS - sulphone } \\
\text { Group } C & \ldots & \text { M.A. + DDS - Marianum } \\
& & \text { Antigen and sulphone. }
\end{array}
$$

The usual dose of Marianum Antigen was from 0.03 to $0 . \mathrm{I} \mathrm{ml}$, given by intradermal injection in the deltoid region of the shoulder, once a month for periods of six months, and occasionally stopping for a month.

In Group B and C the initial dose of DDS was $50 \mathrm{mg}$ a week given orally for the first two weeks; I $00 \mathrm{mg}$ a week for the second two weeks, with a gradual increase until the maximum dose of 600 mg a week was reached.

Clinical examinations, dermatological and neurological, were made by the doctors once a month, while bacteriological examination, generally, was made only in the lepromatous type by the modifications of Wade's method two to four times a year. 
Classification of Patients by Clinics

\begin{tabular}{|c|c|c|c|c|}
\hline \multirow[b]{2}{*}{ Group } & \multicolumn{4}{|c|}{ No. of Patients Participating } \\
\hline & $\begin{array}{l}\text { Dr Bagalawis' } \\
\text { Clinic }\end{array}$ & $\begin{array}{l}\text { Dr Oh's } \\
\text { Clinic }\end{array}$ & $\begin{array}{l}\text { Dr Whang's } \\
\text { Clinic }\end{array}$ & Total \\
\hline Group A on M.A. & 509 & $\mathrm{I}, 548$ & 445 & 2,502 \\
\hline Group B on DDS & г96 & 71 & I 7 & 284 \\
\hline Group C on M.A. plus DDS & 83 & - & - & 83 \\
\hline Total & 788 & I,6 I 9 & 462 & 2,869 \\
\hline
\end{tabular}

Of the total number of patients in the three clinics, approximately two-thirds were males; most of the patients were between io and 50 years of age. The ratio of lepromatous to tuberculoid types was I 3 to $\mathrm{I}$.

\section{GLINICAL RESULTS}

The clinical results were summarized as 'Improved' (arrested, markedly or moderately), 'Stationary' or 'Worse'.

In the above table the respective proportion

T A B LE II

\begin{tabular}{|c|c|c|c|c|c|c|c|c|c|c|}
\hline $\begin{array}{l}\text { Therapy Group } \\
\text { and } \\
\text { Type of Disease }\end{array}$ & $\begin{array}{l}\text { No. } \\
\text { of } \\
\text { pts. }\end{array}$ & $\begin{array}{l}\text { Dr Baga } \\
\text { Clinic } \\
\text { Impr. }\end{array}$ & $\begin{array}{l}\text { lawis's } \\
\text { Stat. }\end{array}$ & Worse & $\begin{array}{l}\text { No. } \\
\text { of } \\
\text { pts. }\end{array}$ & $\begin{array}{l}\text { Dr Oh's } \\
\text { Clinic } \\
\text { Impr. }\end{array}$ & Stat. & Worse & $\begin{array}{l}\text { No. } \\
\text { of } \\
\text { pts. }\end{array}$ & $\begin{array}{l}\text { Dr Whang's } \\
\text { Clinic } \\
\text { Impr. Stat. Worse }\end{array}$ \\
\hline $\mathrm{L}$ & 3 I I & $72 \%$ & $17 \%$ & $11 \%$ & 758 & $69 \%$ & $29 \%$ & $2 \%$ & 288 & $67 \% \quad 30 \% \quad 3 \%$ \\
\hline $\mathrm{T}$ & I 98 & $60.6 \%$ & $31.8 \%$ & $7.6 \%$ & 790 & $66 \%$ & $33 \%$ & $1 \%$ & I 57 & $5 \mathrm{I} \% \quad 49 \%$ \\
\hline Total & 509 & $67.8 \%$ & $22.6 \%$ & $9.6 \%$ & $1,54^{8}$ & $68 \%$ & $31 \%$ & I. \% & 445 & 6 I\% $37 \% \quad 2 \%$ \\
\hline $\mathrm{L}$ & I 26 & $66 \%$ & $25 \%$ & $9 \%$ & 44 & $63.6 \%$ & 3 I. $8 \%$ & $4.6 \%$ & I 4 & $57 \% \quad 43 \%-$ \\
\hline $\mathrm{T}$ & 70 & $49 \%$ & $47 \%$ & $4 \%$ & 27 & $52 \%$ & $4^{8 \%}$ & - & 3 & $67 \% 33 \%-$ \\
\hline Total & 196 & $60 \%$ & $33 \%$ & $7 \%$ & $7 \mathbf{I}$ & $59 \%$ & $38 \%$ & $3 \%$ & 17 & $59 \% \quad 41 \%-$ \\
\hline $\mathrm{L}$ & 68 & $72 \%$ & $16 \%$ & $12 \%$ & & & & & & \\
\hline $\mathrm{T}$ & I 5 & $73 \%$ & $20 \%$ & $7 \%$ & & & & & & \\
\hline Total & 83 & $72 \%$ & $17 \%$ & $11 \%$ & & & & & & \\
\hline
\end{tabular}

classified as 'Improved', 'Stationary' and 'Worse' is about the same in each clinic, according to the mode of therapy. On the average 66.5 per cent of the patients were improved in Group A. 59.5 per cent of the patients were improved in Group B, while in Group C, 72 per cent of the patients were improved. The difference of improvement between Group A and B averages approximately at 7 per cent - Group A - Marianum Antigen was more effective than Group B on DDS.

Percentages of 'Arrested' patients out of the 'Improved' - in relation with the length of time of treatment in Dr Oh and Dr Whang's clinics are as follows: 


\begin{tabular}{|c|c|c|c|c|}
\hline \multirow[b]{2}{*}{$\begin{array}{l}\text { Duration of } \\
\text { Treatment } \\
\text { (Year) }\end{array}$} & \multicolumn{2}{|c|}{ Dr Oh's Cilinic } & \multicolumn{2}{|c|}{ Dr Whang's Clinic } \\
\hline & $\begin{array}{l}\text { No. of } \\
\text { improved }\end{array}$ & $\begin{array}{l}\mathcal{N} \text { o. of } \\
\text { arrested } \\
\text { (per cent) }\end{array}$ & $\begin{array}{l}\text { No. of } \\
\text { improved }\end{array}$ & $\begin{array}{l}\text { No. of } \\
\text { arrested } \\
\text { (per cent) }\end{array}$ \\
\hline Ist Year & 220 & - & 48 & - \\
\hline 2nd Year & 235 & $0.4 \%$ & $5^{8}$ & I. $7 \%$ \\
\hline $3^{\text {rd Year }}$ & 198 & $20.2 \%$ & 43 & $27 \cdot 9 \%$ \\
\hline $4^{\text {th }}$ Year & I 5 I & $51.1 \%$ & $5^{I}$ & $56.9 \%$ \\
\hline $5^{\text {th }}$ Year & I 33 & $83 \cdot 7 \%$ & 37 & $67.6 \%$ \\
\hline 6th Year & 85 & $88.2 \%$ & 34 & $94 \cdot 1 \%$ \\
\hline 7 th Year & 25 & $92.0 \%$ & 2 & $100.0 \%$ \\
\hline Total & $\mathrm{I}, 047$ & $25 \cdot \mathbf{1} \%$ & 273 & $\mathbf{3 7 . 0} \%$ \\
\hline
\end{tabular}

(Arrested patients were defined according to the description of the 'Inactive' cases adopted by the VIIth International Congress on Leprology in Tokyo).

Although the proportion of 'Arrested' patients is remarkably increased after $2 \frac{1}{2}$ years treatment, there is a big difference of percentages obtained in the two clinics - 25 per cent of Dr Oh's patients, against 37 per cent for Dr Whang's. Such difference may be related to the stage of the disease among the selected patients.

Table 4 shows percentages of improvement obtained among Dr Bagalawis's patients, according to the duration of treatment (three years) in the different therapy.

T A B L E I V

\section{Therapy Groups}

\begin{tabular}{|c|c|c|c|c|c|c|}
\hline \multirow{2}{*}{$\begin{array}{l}\text { Duration of } \\
\text { Treatment }\end{array}$} & \multicolumn{2}{|c|}{ A. on $M . A$} & \multicolumn{2}{|c|}{ B. on $D D S$} & \multicolumn{2}{|c|}{ C. on M.A. and sulphone } \\
\hline & $\begin{array}{l}\text { No. of } \\
\text { patients }\end{array}$ & $\begin{array}{l}\text { No. of } \\
\text { Impr. } \\
\text { (per cent) }\end{array}$ & $\begin{array}{l}\text { No. of } \\
\text { patients }\end{array}$ & $\begin{array}{l}\text { No. of } \\
\text { Impr. } \\
\text { (per cent) }\end{array}$ & $\begin{array}{l}\text { No. of } \\
\text { patients }\end{array}$ & $\begin{array}{l}\text { No. of } \\
\text { Impr. } \\
\text { (per cent) }\end{array}$ \\
\hline Ist Year & $3^{1} 6$ & $62.0 \%$ & 80 & $53 \cdot 7 \%$ & 29 & $58.6 \%$ \\
\hline 2nd Year & 122 & $71 \cdot 3 \%$ & 76 & $59.2 \%$ & $3^{I}$ & $71.0 \%$ \\
\hline 3rd Year & 35 & $77.1 \%$ & 39 & $71.8 \%$ & I 4 & $85 \cdot 7 \%$ \\
\hline Total & 473 & $65 \cdot 5 \%$ & 195 & $59 \cdot 5 \%$ & 74 & $68.9 \%$ \\
\hline
\end{tabular}

In the above Table, improvement is obtained more rapidly in Group A than in Group B, in the first three years of treatment; but Group C shows a higher percentage of improved cases, than the other two groups for the same length of time.

Leprosy reaction was present during the course of treatment in 20.7 per cent (E.N.L. 25.2 per cent, and $\mathrm{I} 6.3$ per cent of reaction in tuberculoid cases) of Dr Oh's clinic; and 32. I per cent of Dr Whang's clinic in Group A; they occurred more frequently in the first to second years of treatment, without any clear relationship to the therapy group.
Ocular complicatons were present on preliminary examinations in I $5^{8}$ patients in Dr Oh's clinic, and 58 patients in Dr Whang's clinic.

The clinical results of these patients were as follows :

DR OH's

66 improved; 79 stationary; I 3 worse DR WHANG's

8 improved; 35 stationary; I 5 worse

The loss of eyebrows was commonly seen in lepromatous patients; among the patients classified as 'Arrested' in Group A, 63 patients in Dr Oh's clinic, and 4I patients in Dr Whang, had 
their eyclorows grown again, while none was observed in Group I3 patients.

Gynaecomastia was recorded as healed in four patients out of I 2, by Dr Oh; and I o patients out of I 3 by Dr Whang, in Group A, without any sexual hormone treatment.

The general condition of the patients remained good in all therapy groups, even among those classified as 'Stationary' in all the clinics.

For the bacteriological examinations of lepromatous patients, smears were taken from both sides of the nasal septum, both earlobes, and other optional skin sites, and subsequent smears were from approximately the same areas. The present analysis deals only with Group $\Lambda$, in the preliminary and final results.

Three grades in a positive finding were designated as follows:

\begin{tabular}{|c|c|}
\hline Negative & .. no bacilli found in roo \\
\hline One-plus & $\begin{array}{l}\text {. rare, one or less than one } \\
\text { bacillus in each microscopic } \\
\text { field. }\end{array}$ \\
\hline Two-plus & $\begin{array}{l}\text {. numerous, bacilli found in } \\
\text { all field. }\end{array}$ \\
\hline Three-plus & $\begin{array}{l}\text { abundant, many bacilli in } \\
\text { all field. }\end{array}$ \\
\hline
\end{tabular}

TABLE V

Bacteriological Findings on Preliminary Examination

\begin{tabular}{llc} 
Results & Dr Oh's Clinic & Dr Whang's Clinic \\
Negative & $\mathrm{I} 68(22 \%)$ & $55(\mathrm{I} 9 \%)$ \\
Positive + & $332(44 \%)$ & $\mathrm{I} 2(39 \%)$ \\
Positive ++ & $\mathrm{I} 75(23 \%) 590(78 \%)$ & $74(26 \%) 233(8 \mathrm{1} \%)$ \\
Positive +++ & $83(\mathrm{I} \%)$ & $47(\mathrm{I} 6 \%)$ \\
\hline \multicolumn{1}{c}{ Total } & $758(100 \%)$ & $288(100 \%)$
\end{tabular}

Seventy-eight per cent of all lepromatous patients were positive at the outset as by Dr Oh, compared to $8 \mathrm{I}$ per cent by Dr Whang. Of all positive patients who completed treatment, the proportions becoming negative were 83.6 per cent (493) by Dr Oh and 82.8 per cent (I 93) by Dr Whang. The remaining patients were never heavily positive except $\mathrm{I} 2$ of them by $\mathrm{Dr} \mathrm{Oh}$ and nine of them by Dr Whang.

\section{IS G USS I O N}

In the treatment of leprosy, Marianum Antigen was given for large scale trials by stationary and mobile clinics, while the other two groups (Group B on DDS and Group C on M.A. plus DDS) were used for control.

Comparing the results in the three therapy groups, Group C on M.A. plus DDS which was experimented by Dr Bagalawis, has shown better results than the other two therapy groups, however the number of selected patients was too small and no significant control group was made by any doctor. Therefore, it may be advisable to have more experimental study in the future.
The results between Group A on M.A. and Group B on DDS Group A was slightly better benefit than Group B. On the average 66.5 per cent of the patients were clinically improved in Group A, against 59.5 per cent in Group B.

The proportions recorded as stationary were relatively high at all clinics. The reason seems due to the different concept of the doctors for the state of the disease and also there are many difficult problems to judge clinical change in patients. These patients who were classed as stationary may be either improved or arrested.

The present paper includes some inmates of the leprosaria treated by Dr Bagalawis and most of them received prior to sulphone therapy. Thus clinical changes were recorded considerably more frequent in patients with prior sulphone treatment than in others.

During the treatment at the stationary and mobile clinics, 25 patients who had gynaecomastia were treated on M.A. alone without any sexual hormone. Out of 25, the symptoms of I 4 patients were healed or disappeared, however it is doubtful whether the improvement was attributed to therapy or not. 
In the majority of the patients who received M.A. treatment, there appeared at the injection site an erythematous papule (sore). After that, it showed an ulcer sometimes due to secondary infection, but it healed with scar within the month. A few patients had lymphangitis in the local area and a less number had general reactions such as: fever, headache, dizziness and rarely pruritis, etc., but these usually disappeared after a few days to two weeks.

The patients have been supplied with food and relief goods when possible. It would be very helpful for patients to be treated regularly.

It was found that M.A. therapy is more effective for patients visited once or twice a month by mobile clinics than sulphone drugs administered orally, because M.A. is non-toxic and the doctor controls the exact dosage.

\section{S U M M A R Y}

(I) This is a controlled study of leprosy patients which was carried out by stationary and mobile clinics using the antigenotherapy of Marianum Antigen. Among 6,605 registered by three of seven doctors, 2,869 were selected for the report. Out of 2,869, 2,502 were treated with M.A. up to $7 \frac{1}{2}$ years in standard dosage, 287 with only DDS and 83 received M.A. plus DDS for comparison. (2) Both M.A. and DDS therapies were well tolerated. In this study the Group on M.A. showed slightly better clinical improvement than the Group on DDS. The clinical effect of M.A. is seen in the following results : 4.2 per cent did not benefit; 30.2 per cent remained stationary; and 65.6 per cent continued to improve in general conditions and in specific lesions such as : infiltration, nodules, ulcers, maculae, nerve enlargement and others until arrested.

(3) The lepromatous type showed higher proportion of improvement than tuberculoid type. To the patients who became arrested after $2 \frac{1}{2}$ years on M.A. a maintenance dose was given for the next three or four years. $\mathcal{N}$ o relapse occurred.

(4) No evidence was obtained that clinical improvement may be related to age or sex.
(5) In the lepromatous type $83 \cdot 4$ per cent among the patients who were bacteriologically positive were converted to negative.

(6) Patients with leprosy reaction or ocular complictaions received about a half the standard dosage of M.A. or DDS with symptomatic treatment, usually with beneficial effect.

This report was compiled and edited by Shi Riong Choi, M.D. and D.P.H. Leprologist of R.O.K. Ministry of Health and Social Affairs, after careful study of the voluminous reports of Drs Bagalawis, Oh and Whang, and of thesis charts on individual patients.

\section{R E F E R E N GES}

I BACKETT, D. W. A trial of antigen as an adjunct of DDS in the treatment of lepromatous leprosy. Leprosy Rev., 29 ( 1958), pp. 209-2 I 4 .

2 Blanc, m., and prost, м. T. Clinical and therapeutic study of an antigen with Mycobacterium marianum, applied to 457 leprosy patients. Internat. 7. Leprosy, 23 (I 955), 23-30.

3 BLANC, M. PRost, M. T. and MARIE-SuZAnne, Sr. Influence of the injection of suspension of a mycobacterium isolated from a leprosy patient (Chauvire strain) on the Mitsuda reaction. Bull. Soc. Path. exot., 46 (1953), ıoo9IOI 5 .

4 Ghaussinand, R. and viette, M. Can mycobacterium vaccination be used in the prevention and treatment of leprosy? Bull. Acad. Nation. Med., 139 (I 955), I65-169.

5 Doull, J. A. and wolcott, R. R. Treatment of leprosy I, Chemotherapy. New England 7. Med., 254 (1956), 20-25.

6 montestruc, E. New trials in antileprosy therapy. Bull Soc. Path. exot., 49 ( I 956), I O-I 5.

7 Ondoua, P., Prost, M. T. and DE LA Trinite, M. Clinical and immunological results obtained with the marianum antigen after more than ten years of therapeutic use. Leprosy Rev., 35 ( I 964), 297-303.

8 RELVich, A. L. Experience with antigen marianum in the treatment of leprosy. Leprosy Rev., 28 (I 957), I 50-I 56. 9 SEN, N. and MUKerJeE, N. Antigen marianum in the treatment of leprosy. Bull. Calcutta Sch. Trop. Med., 5 (1957), 32.

Io TOLEnTino, J. G. Results of six months supplementary treatment of lepromatous patients with mycobacterium marianum vaccine. Internat. 7. Leprosy, 25 (I 957), 35 I-355. I I GIUSEPPE PENSO, ROBERT NOEL, MICHEL BLANC, SOEUR MARIE SUZANNe, Etudes et Recherches sur les Mycobacteries. Estratto dai Rendiconti dell'Academia Nationale del XL Serie IV - Vol. VIII, 80 ${ }^{\circ}$ della fondazione I957, Roma. 